\title{
Efektivitas Konseling Kelompok Teknik Token Ekonomi untuk Meningkatkan Sikap Tanggung Jawab Akademik Mahasiswa
}

\author{
Leny Latifah ${ }^{\text {a, }}{ }^{*}$, Khairul Bariyyah ${ }^{\text {b, } 2}$ \\ ${ }^{a}$ b Universitas Kanjuruhan Malang, Indonesia \\ 1 lenylatifah@unikama.ac.id ${ }^{*}$; ${ }^{2}$ khairulbariyyah@unikama.ac.id \\ *korespondensi penulis
}

\begin{tabular}{l} 
Informasi artikel \\
\hline Received : \\
December 16, 2019. \\
Revised : \\
January 01, 2019. \\
Publish : \\
January 31, 2020. \\
Kata kunci: \\
tanggung jawab \\
akademik \\
konseling kelompok \\
token ekonomi \\
mahasiswa
\end{tabular}

Keywords:

academic

responsibilities

group counseling

token economy

students

\begin{abstract}
ABSTRAK
Sikap tanggung jawab akademik adalah suatu sikap yang penting dan harus dimiliki oleh mahasiswa saat ini sebagai penunjang dalam meningkatkan kualitas belajar. Penelitian ini dilakukan dengan maksud untuk membantu mahasiswa meningkatkan sikap tanggung jawab akademik dengan menggunakan salah satu strategi layanan dalam bimbingan dan konseling, yaitu konseling kelompok dengan teknik token ekonomi. Penelitian ini termasuk quasi experimental dengan menggunakan desain one group pretest-posttest. Berdasarkan perbandingan pretest dan posttest diketahui bahwa delapan mahasiswa mengalami kenaikan sikap tanggung jawab akademik. Setelah pemberian treatment, subjek penelitian terlihat lebih berani mengungkapkan pendapat, lebih percaya diri untuk bertanya, lebih tanggap akan tugas yang diberikan, serta mampu menyampaikan dan melaksanakan komitmen untuk memperbaiki diri. Selain itu ketepatan pelatih dalam penerapan langkah-langkah pelaksanaan token ekonomi dan kesesuaian dalam pemberian hadiah menjadikan faktor meningkatnya sikap tanggung jawab akademik. Dapat disimpulkan bahwa konseling kelompok teknik token ekonomi efektif untuk meningkatkan sikap tanggung jawab akademik mahasiswa program studi bimbingan dan konseling.
\end{abstract}

\begin{abstract}
The attitude of academic responsibility is an important attitude and must be owned by the current students as supporting in improving the quality of learning. This research is done with the intention to help students improve the attitude of academic responsibility by using one of the service strategies in guidance and counseling, namely group counseling with economic token engineering. This research includes experimental quasi using one group pretest-posttest design. Based on pretests and posttest comparisons it is known that eight students experience a rise in academic responsibilities. After the treatment, the research subject looks more daring to express opinion, more confident to ask, more perceptive to the task given, and able to convey and implement a commitment to improve. In addition, the accuracy of the trainer in implementing the measures of implementation of economic tokens and suitability in awarding gifts makes an increasing attitude of academic responsibility. It can be concluded that the counseling economic engineering group is effective to improve the academic responsibility attitude of student study and counseling programs.
\end{abstract}

Copyright (C) 2020 (Leny Latifah \& Khairul Bariyyah). All Right Reserved

How to Cite: Latifah, L., \& Bariyyah, K. (2020). Efektivitas Konseling Kelompok Teknik Token ekonomi Untuk Meningkatkan Sikap Tanggung Jawab Akademik Mahasiswa. Jurnal Inspirasi Pendidikan, 10(1), 51-56.

This work is licensed under a Creative Commons Attribution-ShareAlike 4.0 International License. Allows readers to read, download, copy, distribute, print, search, or link to the full texts of its articles and allow readers to use them for any other lawful purpose. The journal hold the copyright. 


\section{Pendahuluan}

Pendidikan yang berkualitas dan bermutu dapat ditentukan oleh kualitas profesional pendidik, peserta didik, sarana dan prasarana, media pendidikan, serta sistem evaluasi (Sinambela 2017). Selain menjadi penentu kualitas pendidikan, komponen tersebut diatas merupakan bagian penting yang harus mendapatkan perhatian sebagai salah satu strategi penguatan dalam pembelajaran (Polii 2016). Peserta didik dalam penelitian ini yaitu individu yang berada pada jenjang perguruan tinggi atau disebut mahasiswa merupakan salah satu penentu kualitas pendidikan yang akan datang. Tuntutan belajar dikampus yang cukup tinggi membuat mahasiswa di zaman modern ini harus belajar lebih mandiri, terarah, dan bertanggung jawab (Arfiah and Sumardjoko 2017). Hal ini sejalan dengan pemikiran (Clemes and Bean 1990) bahwa kunci keberhasilan prestasi anak berawal dari tanggung jawab. Hal ini dapat dikatakan sebagai tanggung jawab akademik.

Pentingnya tanggung jawab akademik bagi mahasiswa adalah agar ia tidak mengalami kegagalan atau kerugian dalam perkuliahan yang ditempuhnya, karena dengan adanya sikap tanggung jawab akademik, mahasiswa akan mendapatkan hak seutuhnya dari hasil perkuliahan yang ditempuhnya tersebut (Mardelina and Muhson 2017). Jika mahasiswa memiliki sikap tanggung jawab akademik, maka secara langsung akan meningkatkan kualitas belajar yang semakin baik, mampu menyelesaikan tugas dan perkuliahan, memiliki sikap kepedulian terhadap diri sendiri, teman, dan lingkungan disekitarnya dalam hal akademik.

Kurangnya sikap tanggung jawab akademik mahasiswa dapat membawa pada bentuk perilaku yang negatif dan kurang baik bagi diri mahasiswa (Rahmayati and Lubis 2017). Hal ini terjadi pada mahasiswa Bimbingan dan Konseling, Universitas Kanjuruhan Malang yang ditunjukkan dengan perilaku seperti datang terlambat ke kampus, tidak jujur dalam mengerjakan ujian (mencontek), tidak mengerjakan tugas, tidak mengumpulkan tugas tepat waktu, dan tidur pada saat perkuliahan. Fenomena ini terjadi karena mahasiswa mengalami tekanan dalam bidang akademik yang menyebabkan perasaan bimbang (Nor and Ilias 2013).

Pada penelitian ini, peneliti bermaksud untuk meningkatkan tanggung jawab akademik mahasiswa melalui salah satu strategi dalam Bimbingan dan Konseling, yaitu konseling kelompok (Chen and Rybak 2017). Hal ini karena konseling kelompok merupakan salah satu layanan yang dapat digunakan untuk membantu individu fokus pada gejala masalah yang tampak, mengajarkan strategi pemecahan masalah, dan dirancang dalam waktu yang relatif singkat sehingga dapat mempercepat terjadinya perubahan pada individu (Corey 2011). Pelaksanaan konseling kelompok tentunya memerlukan teknik yang sesuai dengan permasalahan yang terjadi (Jawandi, Sugiharto, and Tadjri 2016). Teknik yang digunakan dalam konseling kelompok pada penelitian ini adalah teknik token ekonomi untuk meningkatkan sikap tanggung jawab akademik mahasiswa. Karena token ekonomi adalah modifikasi perilaku yang disusun secara sistematis dengan tujuan meningkatkan perilaku positif yang diinginkan. (Erford 2016) berpendapat bahwa teknik token ekonomi adalah bentuk penguatan positif dimana token akan segera diberikan kepada individu dengan cepat setelah perilaku yang diinginkan tampak.

Menurut (Martin and Joseph 2015) token ekonomi memiliki dua manfaat yaitu dapat diberikan langsung setelah perilaku yang diinginkan muncul, dan ditukarkan pada waktu berikutnya untuk mendapatkan penguatan pendukung. Jadi, token dapat digunakan sebagai jembatan bagi penundaan cukup lama antara respons target dan penguat pendukung, khususnya ketika penguat sulit atau tidak dapat diberikan langsung mengikuti perilaku (Schaefer and Martin 1969). Selanjutnya token yang dipasangkan dengan banyak penguat pendukung dapat menjadi penguat terkondisikan umum yang karenanya tidak lagi bergantung pada operasi motivasi tertentu untuk memperoleh kekuatannya. Hal ini memudahkan dalam pemberian penguat-penguat yang konsisten dan efektif ketika menangani sekelompok individu yang jelas berbeda taraf motivasinya satu sama lain.

\section{Metode}

Penelitian ini merupakan quasi experimental dengan menggunakan desain one group pretestposttest yang bertujuan untuk mengetahui perbandingan kondisi awal dan kondisi akhir setelah diberikan perlakuan (Creswell and Creswell 2017). Penelitian ini dilakukan pada mahasiswa Program 
Studi Bimbingan dan Konseling Universitas Kanjuruhan Malang dengan responden berasal dari mahasiswa angkatan 2019. Subjek penelitian adalah delapan orang mahasiswa yang memiliki skor sikap tanggung jawab akademik tergolong rendah. Instrumen yang digunakan pada penelitian ini adalah skala sikap tanggung jawab akademik yang digunakan untuk mengukur sikap tanggung jawab akademik mahasiswa sebelum dan sesudah diberikan treatment yang dikembangkan sendiri oleh peneliti. Tingkat reliabilitas dari skala sikap tanggung jawab akademik sebesar 0,947. Item lama sebanyak 28 butir. Media analisis data menggunakan SPSS 22 untuk mengidentifikasi reliabilitas dan validitas. Data sikap tanggung jawab akademik yang diperoleh dianalisis menggunakan uji Wilcoxon dengan media analisis data SPSS 22, sehingga data yang dihasilkan berupa kategorisasi sikap tanggung jawab akademik mahasiswa bimbingan dan konseling Universitas Kanjuruhan Malang.

Pelaksanaan treatment dilakukan selama tujuh kali pertemuan yang dilaksanakan pada bulan Mei 2019. Kegiatan awal yaitu mengajak 8 mahasiswa yang sudah terpilih untuk melaksanakan kegiatan konseling kelompok di ruang konseling kelompok Universitas Kanjuruhan Malang. Konseling kelompok pada pertemuan pertama dimulai dengan perkenalan antar anggota kelompok dan juga perkenalan dari peneliti, dilanjut dengan penjelasan pelaksanaan kegiatan, tugas tanggung jawab yang harus dilakukan oleh mahasiswa selama mengikuti kegiatan konseling kelompok, dan asas-asas yang terdapat dalam konseling kelompok. Pada pertemuan kedua peneliti melakukan assesment terhadap anggota kelompok dengan mengarahkan anggota kelompok agar mampu mengidentifikasi perilaku akademik yang kurang bertanggungjawab, selanjutnya menanyakan pada anggota kelompok terkait perilaku yang ingin di ubah serta menggali alasan atas munculnya sikap akademik yang kurang bertanggungjawab selama ini. Pertemuan ketiga dilakukan untuk menyepakati penggunaan teknik token ekonomi dalam konseling kelompok, selanjutnya peneliti mengarahkan anggota kelompok untuk menentukan tujuan konseling, menjelaskan dan melakukan penekanan kembali bahwa kegiatan yang dilakukan adalah untuk meningkatkan sikap tanggung jawab akademik, serta memberikan kesempatan kepada anggota kelompok untuk mengajukan pertanyaan terkait hal yang sudah dilaksanakan. Pertemuan keempat dan kelima pemecahan masalah menggunakan teknik token ekonomi dengan membahas masalah konseli secara kelompok, memilih jenis token yang akan digunakan, memilih penguat pendukung/hadiah berupa barang dan aktivitas yang secara alamiah tersedia dan apa pun yang dipandang penting bagi individu, mengelola penguat dengan cara mengetahui seberapa sering penguat tersedia untuk bisa disediakan. Kegiatan ini memiliki tujuan untuk pengentasan masalah anggota kelompok, selain itu juga memandirikan anggota untuk menemukan perilaku baru yang positif, memberikan pengalaman bekerjasama didalam kelompok. Pertemuan keenam pengisian lembar refleksi yang sudah disediakan, kemudian dilanjutkan dengan pengakhiran konseling. Kegiatan pertemuan ketujuh yaitu postest.

\section{Hasil dan Pembahasan}

Sikap tanggung jawab akademik sebelum (pretest) dan setelah (postest) pemberian konseling kelompok teknik token ekonomi terhadap delapan sampel penelitian dideskripsikan melalui dan tabel 1 sebagai berikut:

Tabel 1. Hasil Pretest dan Postest Sikap Tanggung Jawab Akademik Mahasiswa

\begin{tabular}{ccccc}
\hline \multirow{2}{*}{ Nama } & \multicolumn{5}{c}{ Skor } \\
\cline { 2 - 5 } & Pretest & Kategori & Postest & Kategori \\
\hline RRM & 57 & Rendah & 112 & Tinggi \\
AP & 56 & Rendah & 128 & Sangat Tinggi \\
HFD & 67 & Sedang & 125 & Sangat Tinggi \\
FNK & 66 & Sedang & 111 & Tinggi \\
MAH & 42 & Rendah & 119 & Sangat Tinggi \\
RF & 60 & Rendah & 120 & Sangat Tinggi \\
MFM & 48 & Rendah & 114 & Tinggi \\
YAP & 54 & Rendah & 122 & Sangat Tinggi \\
\hline
\end{tabular}


Berdasarkan hasil posttest diketahui bahwa delapan mahasiswa yang memiliki skor sikap tanggung jawab akademik rendah mengalami kenaikan pada sikap tanggung jawab akademik, hal ini diketahui dari skor pretest dimana delapan mahasiswa ini memiliki sikap tanggung jawab akademik yang rendah namun setelah mendapatkan treatment berupa konseling kelompok teknik token ekonomi, skor tanggung jawab akademik mahasiswa mengalami peningkatan. Analisis dilakukan setelah pengumpulan data sikap tanggung jawab akademik berupa angket yang telah diisi mahasiswa setelah pemberian konseling kelompok teknik token ekonomi. Data yang dikumpulkan dari penelitian ini dianalisis menggunakan uji Wilcoxon, berikut tabelnya:

Tabel 2. Uji Wilcoxon
\begin{tabular}{|l|r|}
\hline & Post Test - Pre Test \\
\hline Z & $-2,524^{\mathrm{b}}$ \\
\hline Asymp. Sig. (2-tailed) &, 003 \\
\hline
\end{tabular}

a. Wilcoxon Signed Ranks Test

b. Based on positive ranks.

Dari tabel 2 dapat dilihat bahwa hasil perhitungan Sig. (2-tailed) adalah 0,003. jika peluang signifikasi $>0,05$ maka $\mathrm{H} 0$ ditolak dan sebaliknya jika peluang signifikasi $<0,05$ maka Ha diterima. Berdasarkan hasil yang diperoleh Sig. (2-tailed) 0,003 $<0,05$ maka dapat disimpulkan Ha diterima dan H0 ditolak. Artinya konseling kelompok teknik token ekonomi efektif untuk meningkatkan sikap tanggung jawab akademik mahasiswa karena reward yang diberikan sesuai dengan keperluan mahasiswa saat ini yaitu paket data internet 1 GB dan 2 GB. Hasil pretest sikap tanggung jawab ratarata tergolong dalam kategori sedang dan rendah, hal ini mungkin dapat disebabkan karena mahasiswa merasa kesulitan dengan mata kuliah tertentu sehingga timbul rasa bosan dan bersikap tidak bertanggung jawab.

Menurut (Sudani, Suarni, and Setuti 2013) faktor - faktor yang mempengaruhi sikap tanggung jawab seorang individu diantaranya adalah pengaruh pergaulan di lingkungan sekitar, adanya perkembangan media elektronik, kurangnya kesadaran mahasiswa tersebut akan pentingnya melaksanakan hak dan kewajiban yang merupakan tanggung jawabnya, kurang memiliki sikap percaya diri terhadap kemampuan yang dimiliki, dan kurangnya kesadaran mahasiswa akan pentingnya tugas yang diberikan. Kebiasaan mengulur waktu untuk menyelesaikan tugas sering dilakukan oleh mahasiswa. Hal ini memiliki dampak terhadap proses perkuliahan. Selain itu, mengulur waktu juga dapat menyebabkan terlambatnya pengumpulan tugas, cemas sebelum ujian, sikap putus asa pada mahasiswa dan lebih jauh lagi mempengaruhi aktivitas lainnya pada lingkungan kampus. Menurut (Solomon and Rothblum 1984) keyakinan irasional akan muncul pada pelajar dalam mempersiapkan tugas sekolah dikarenakan motif mahasiswa yang memandang tugas sebagai sesuatu yang berat dan tidak menyenangkan (aversineves of the task dan fear of failure), yaitu ketakutan yang berlebihan untuk gagal, mahasiswa menunda-nunda mengerjakan tugas sekolah karena takut jika gagal menyelesaikannya sehingga akan mendatangkan penilaian yang negatif akan kemampuannya. Adapun penelitian sebelumnya yang berkaitan dengan teknik token ekonomi yang dilakukan oleh (Qurbi 2015) menunjukkan bahwa teknik token ekonomi efektif untuk mengembangkan tanggung jawab peserta didik dan skor tanggung jawab paling besar diperoleh pada aspek kegigihan. Keterbaruan dalam penelitian ini pada subjek penelitian, yaitu mahasiswa, hal ini membuktikan bahwa token ekonomi dapat digunakan kepada segala usia, untuk meningkatkan atau menurunkan perilaku yang diinginkan oleh peneliti, sesuai dengan teori yang ada.

Dari berbagai pembahasan yang disajikan peneliti dapat disimpulkan bahwa, kebiasaan menunda-nunda pekerjaan akademik, adanya ketakutan yang berlebihan untuk gagal serta kurangnya kesadaran mahasiswa tersebut akan pentingnya melaksanakan hak dan kewajiban yang merupakan tanggung jawabnya dapat mempengaruhi aktivitas seseorang dalam lingkungan sekolah maupun kampus. Dengan adanya penelitian token ekonomi ini diharapkan keadaan tersebut tidak berlarut-larut dan dapat segera ditangani, seorang mahasiswa diharapkan untuk memiliki kesadaran akan hak dan 
kewajibannya serta gigih dalam melaksanakan keduanya. Sehingga memiliki sikap tanggung jawab akademik yang dimiliki.

\section{Simpulan}

Terdapat peningkatan skor sikap tanggung jawab akademik mahasiswa dari sebelum dan sesudah diberikan perlakuan konseling kelompok teknik token ekonomi. Demikian juga konseling kelompok teknik token ekonomi efektif untuk meningkatkan sikap tanggung jawab akademik mahasiswa program studi bimbingan dan konseling. Saran untuk konselor perguruan tinggi yaitu dapat menjadikan teknik token ekonomi sebagai salah satu alternatif dalam upaya membantu memecahkan persoalan konseli melalui proses yang lebih berwarna. Bagi peneliti lanjutan, disarankan dapat mengganti reward yang disesuaikan dengan kebutuhan subjek yang diteliti, dan untuk mendapatkan hasil yang lebih akurat maka token ekonomi dapat diterapkan dalam konseling individual.

\section{Referensi}

Arfiah, Sri, and Bambang Sumardjoko. 2017. "Penguatan Karakter Tanggung Jawab Dan Kemandirian Pada Mahasiswa PPKN Melalui Perkuliahan Kepramukaan Dalam Upaya Mempersiapkan Mutu Lulusan Sebagai Pembina Ekstrakurikuler Di Sekolah.” Jurnal Pendidikan Ilmu Sosial 27(2):76-92.

Chen, Mei-whei, and Christopher Rybak. 2017. Group Leadership Skills: Interpersonal Process in Group Counseling and Therapy. SAGE Publications.

Clemes, Harris, and Reynold Bean. 1990. How to Teach Children Responsibility. Los Angeles: Price Stern Sloan.

Corey, Gerald. 2011. Theory and Practice of Counseling and Psychotherapy. Belmot, CA: Brooks/Cole.

Creswell, John W., and J. David Creswell. 2017. Research Design: Qualitative, Quantitative, and Mixed Methods Approaches. Thousand Oaks, CA: Sage Publications.

Erford, Bradley T. 2016. 40 Teknik Yang Harus Diketahui Setiap Konselor. Yogyakarta: Pustaka Pelajar.

Jawandi, Ahmad, D. Y. P. Sugiharto, and Imam Tadjri. 2016. "Efektivitas Bimbingan Kelompok Teknik Gamestorming Dan Teknik Token Economy Untuk Meningkatkan Kreativitas Siswa SMP Islam Diponegoro Surakarta." Jurnal Bimbingan Konseling 5(2):78-85.

Mardelina, Elma, and Ali Muhson. 2017. "Mahasiswa Bekerja Dan Dampaknya Pada Aktivitas Belajar Dan Prestasi Akademik." Jurnal Economia 13(2):201-9.

Martin, G., and P. Joseph. 2015. Modifikasi Perilaku. edited by Yudi Santoso. Yogyakarta: Pustaka Pelajar.

Myrick, Robert D. 2012. Developmental Guidance and Counseling: A Practical Approach. ERIC.

Nor, Mubin Md, and Kamaruddin Ilias. 2013. "Practice Teaching and Learning Using Interactive Multimedia Innovation for Non-Optional Teachers Teaching in Music Educations." Academic Research International 4(2):338.

Polii, Bernadainty D. 2016. "Penyelenggaraan Otonomi Pendidikan Dan Tanggung Jawab Pemerintah Pada Sistem Pendidikan Nasional Di Indonesia." PEDAGOGIA Jurnal Ilmiah Pendidikan 8(2):430-35.

Qurbi, Abdullah. 2015. "Efektivitas Bimbingan Kelompok Melalui Teknik Storytelling Untuk Mengembangkan Tanggung Jawab Peserta Didik (Penelitian Eksperimen Kuasi Terhadap Peserta Didik Kelas VII SMP PGRI 3 Kota Bandar Lampung Tahun Ajaran 2014/2015).”

Rahmayati, T. Elfira, and Zulkarnain Lubis. 2017. "Hubungan Efikasi Diri Akademik Dan Dukungan Sosial Dengan Penyesuaian Diri." Analitika 5(2):43-49.

Schaefer, H. H., and P. L. Martin. 1969. Behavioral Therapy. New York: McGraw-Hill.

Sinambela, Lijan Poltak. 2017. "Profesionalisme Dosen Dan Kualitas Pendidikan Tinggi." Jurnal Sosial Dan Humaniora 2(4).

Solomon, Laura J., and Esther D. Rothblum. 1984. "Academic Procrastination: Frequency and Cognitive-Behavioral Correlates.” Journal of Counseling Psychology 31(4):503. 
Jurnal Inspirasi Pendidikan, VOL.10, NO.1, Edisi Januari 2020

Efektivitas Konseling Kelompok Teknik Token ekonomi Untuk Meningkatkan Sikap Tanggung Jawab

Akademik Mahasiswa

Leny Latifah ${ }^{1}$, Khairul Bariyyah ${ }^{2}$

Hal: $51-56$

Sudani, Ni Ketut, Ni Ketut Suarni, and Ni Made Setuti. 2013. "Penerapan Konseling Eksistensial Humanistik Teknik Pemodelan Untuk Meningkatkan Perilaku Tanggung Jawab Belajar Siswa Kelas VIII E SMP Negeri 1 Sukasada.” Jurnal Ilmiah Bimbingan Konseling Undiksha 1(1).

Walker, Hill M., Nancy Buckley Hiatt, and Nancy K. Buckley. 1974. Token Reinforcement Techniques: Classroom Applications for the Hard-to-Teach Child. EB Press. 